Check for updates

\section{London}

Cite this as: BMJ 2021;372:n503 http://dx.doi.org/10.1136/bmj.n503 Published: 19 February 2021

\title{
Covid-19: Recognise long covid as occupational disease and compensate frontline workers, say MPs
}

Matthew Limb

MPs have stepped up pressure on ministers to recognise "long covid" as an occupational disease and to compensate frontline health and other key workers living with its "debilitating” effects.

The proposal by the All Party Parliamentary Group on Coronavirus has won the backing of 65 MPs and peers, as well as the BMA. ${ }^{1}$

Layla Moran, a Liberal Democrat MP who chairs the group, said that "heroes of the pandemic" who contracted covid-19 while serving the public should be eligible for regular monthly compensation payments. "These are the people who saved our lives, quite literally ... and it's only right we save their livelihoods," she told the BBC's Today programme on 18 February.

Chaand Nagpaul, the BMA's council chair, commented, "The dedication and selflessness shown by healthcare workers over the last year, and the debt of gratitude owed to them, cannot be underestimated."

About one in 10 people with covid-19 continue to experience symptoms beyond 12 weeks. Long covid can present with clusters of symptoms that are often overlapping and fluctuating, including breathlessness, headaches, cough, fatigue, and cognitive impairment.

\section{Financial insecurity}

The All Party Parliamentary Group, in a letter to the prime minister, Boris Johnson, described long covid as the "hidden health crisis of the pandemic" and estimated that 390 ooo people were living with its “debilitating” effects.

The group said that MPs had heard evidence from many frontline health and other key workers who were now unable to work because of their symptoms and who now felt "abandoned."

Moran said, “These are people who we went out to clap for every Thursday evening, and they find themselves unable to do their work having spent their time saving lives." She said that 205 identified symptoms were associated with long covid in previously healthy adults and children and that a national register was needed to document exactly how many people in the UK were affected.

The MPs' group said that Belgium, Denmark, France, Germany, and Spain were among the countries that had already recognised covid-19 as an occupational disease. This would entitle employees and their dependants to protection and compensation if they contracted the virus while working.

A UK compensation scheme could mirror the Armed Forces Compensation Scheme already in place for military veterans, the MPs' letter said. Moran said that this would mean eligible recipients receiving regular monthly payments depending on their circumstances and level of need.

Nagpaul cited harrowing stories from doctors with long covid who were now unable to work and were financially insecure. "It is only right that ministers urgently provide a compensation scheme to support healthcare staff and their families," he said.

The letter appeared as the UK government announced $€ 18.5 \mathrm{~m}$ ( $€ 21.3 \mathrm{~m}$; $\$ 25.9 \mathrm{~m}$ ) of funding for research into long covid. England's health and social care secretary, Matt Hancock, said, "In order to effectively help these individuals we need to better understand long covid and identify therapeutics that can help recovery. This funding will kick start four ambitious projects to do just that."

\section{All Party Group on Coronavirus. https://appgcoronavirus.marchfor-} change.uk/appg_details.

This article is made freely available for use in accordance with BMJ's website terms and conditions for the duration of the covid-19 pandemic or until otherwise determined by BMJ. You may use, download and print the article for any lawful, non-commercial purpose (including text and data mining) provided that all copyright notices and trade marks are retained. 